\title{
ANÁLISE DA INTERFACE ENTRE O DIREITO URBANÍSTICO E O MEIO AMBIENTE PARA O DESENVOLVIMENTO DE CORREDORES ECOLÓGICOS URBANOS NO PLANEJAMENTO URBANÍSTICO
}

Hannah Torres Danciger ${ }^{1}$

Valmirio Alexandre Gadelha Junior ${ }^{2}$

\section{Resumo:}

Os Corredores Ecológicos são conexões que modificam a paisagem natural ao reconstituir o fluxo da diversidade biológica entre ecossistemas naturais, sendo o principal instrumento para a conectividade da paisagem fragmentada no meio urbano e para a conservação da biodiversidade urbana. O presente artigo tem por objetivo analisar a interface do Direito Urbanístico com o meio ambiente a partir do estudo dos Corredores Ecológicos no meio urbano. Para tanto, a partir do estudo da legislação nacional, buscar-se-á demonstrar que o desenvolvimento dos Corredores Ecológicos Urbanos se mostra como uma técnica ambientalmente sustentável para que o planejamento urbano concretize objetivos urbanísticos e ambientais.

\section{Palavras-chave:}

Corredores; Conectividade; Direito; Urbano; Ambiental.

ANALYSIS OF THE INTERFACE BETWEEN URBANISTIC LAW AND THE ENVIRONMENT FOR THE DEVELOPMENT OF URBAN ECOLOGICAL CORRIDORS IN URBANISTIC PLANNING

\footnotetext{
${ }^{1}$ Graduada em Direito pelo Centro Universitário de Brasília - UniCEUB (2018). Mestranda no programa de Direito do UniCEUB na área de Políticas Públicas, Estado e Desenvolvimento. Advogada OAB-DF.

2 Graduado em Direito pela Universidade Federal da Paraíba (2000). Pós-graduado em Direito Processual Civil pelo IDP-DF (2010) e em Direito Constitucional pela Universidade Anhanguera (2013). no programa de Direito do UniCEUB na área de Políticas Públicas, Estado e Desenvolvimento. Advogado da União. Atualmente cedido ao Ministério da Justiça e Segurança Pública para exercício da função de Assessor Especial de Assuntos Legislativos.
} 


\begin{abstract}
:
Ecological Corridors are connections that modify the natural landscape by reconstituting the flow of biological diversity between natural ecosystems, being the main instrument for the connectivity of the fragmented landscape in the urban environment and for the conservation of urban biodiversity. This article aims to analyze the interface between Urban Law and the environment from the study of Ecological Corridors in the urban environment. Therefore, from the study of national legislation, it will be sought to demonstrate that the development of Urban Ecological Corridors is shown as an environmentally sustainable technique for urban planning to achieve urban and environmental objectives.
\end{abstract}

\title{
Keywords:
}

Corridors; Connectivity; Law; Urban; Environmental

\section{INTRODUÇÃO}

O meio ambiente é a estrutura basilar para a manutenção da vida humana e não humana no planeta. Contudo, o crescimento das atividades antrópicas, a densificação populacional, o incremento do desmatamento e a insuficiência na proteção dos ecossistemas naturais aumentam as mudanças na oferta e demanda de serviços ecossistêmicos, enfraquecendo os feedbacks diretos entre estes e sociedades, potencialmente empurrando os sistemas socioambientais para armadilhas que podem levar ao colapso destes (CUMMING et al, 2014).

Tendo em vista o direito fundamental ao meio ambiente ecologicamente equilibrado e a política urbana que deve ordenar o pleno desenvolvimento das funções sociais da cidade e garantir o bem-estar da população, previstos no texto constitucional (BRASIL, 1988), entende-se que é inadiável o cumprimento das legislações urbanísticas e ambientais para contornar a desfragmentação dos ecossistemas naturais e combater os impactos socioambientais e econômicos decorrente do processo de alteração das paisagens multiespécies no antropoceno (TSING, 2019).

A partir desse cenário, verifica-se que os corredores ecológicos reconstituem o fluxo genético entre ecossistemas preservados isoladamente e entre remanescentes de vegetação, garantindo a preservação e a conservação ambiental dos próprios ecossistemas, das espécies e dos seus recursos naturais. Possibilitam, desse modo, que a biorregião seja beneficiada com a 
recuperação de serviços ecossistêmicos, mitigando os impactos ambientais causados pela sociedade moderna. Ademais, a conectividade por meio dos corredores ecológicos é viável política e financeiramente, considerando o envolvimento de múltiplos atores sociais para o seu planejamento e implantação, que passam a desenvolver usos sustentáveis dos recursos da biorregião, criando oportunidades de negócios e atividades que proporcionem a conservação ambiental (MMA, 2020).

No tocante ao meio ambiente urbano, os corredores ecológicos são igualmente necessários para garantir o fluxo das espécies da biodiversidade da fauna e flora urbanos (CAYTON, 2013), e, também, para a manutenção dos serviços ecossistêmicos da região, tais como a regulação do microclima, solo, recursos hídricos, polinização, dentre outros. Ainda, o reflorestamento para a implementação de corredores ecológicos urbanos pode proporcionar um aumento significativo da qualidade de vida da população pelo restabelecimento de áreas verdes que contribuem para a salubridade das infraestruturas cinzas que seriam o espaço urbano (EUR-LEX, 2013).

Considerando o crescimento da população, das atividades humanas e do espaço urbano, o crescente processo de fragmentação das áreas verdes no espaço urbano, a necessidade do restabelecimento da conectividade das áreas para a proteção da biodiversidade urbana e para a melhoria da qualidade do bem-estar da população, e os mandamentos constitucionais e infraconstitucionais que visam a proteção do meio ambiente, o presente artigo tem como objetivo analisar a viabilidade dos corredores ecológicos funcionarem como instrumentos para a desfragmentação da paisagem urbana, por meio de um planejamento urbano que observe a conectividade dos espaços verdes urbanos.

Para atingir o objetivo pretendido, a primeira parte do presente artigo discorrerá sobre a proteção jurídica do meio ambiente. Em seguida, verificar-se-á como o Direito Urbanístico é utilizado para a garantia da salubridade do meio ambiente, analisando-se, para tanto, dispositivos do Estatuto da Cidade sob a ótica da proteção ambiental. Ao final, desenvolver-se-á a ideia do corredor ecológico urbano como técnica ambientalmente sustentável que deve constar no planejamento urbanístico, confirmando-se sua viabilidade e importância como instrumentos para a desfragmentação do espaço urbano e para a promoção do bem-estar da sociedade.

\section{A PROTEÇÃO JURÍDICA DO MEIO AMBIENTE}


A Constituição Federal, no art. 225, assegura a todos o usufruto ao meio ambiente ecologicamente equilibrado, definindo-o como "bem de uso comum do povo e essencial à sadia qualidade de vida, impondo-se ao Poder Público e à coletividade o dever de defendê-lo e preservá-lo para as presentes e futuras gerações" (BRASIL, 1988). O dispositivo constitucional é reconhecido como um direito fundamental de terceira dimensão (STF, 1995) - ou direito de solidariedade e fraternidade -, em razão da imprescindibilidade dos ecossistemas naturais e dos seus recursos para a viabilidade da vida (humana e não humana) do planeta (SARLET; FENSTERSEIFER, 2017).

Por ser um direito fundamental de terceira dimensão, possui importância não somente na esfera nacional, mas, também, no plano internacional, uma vez que transcende a titularidade individual atingindo uma titularidade transindividual, visto a implicação universal (SARLET, 2015) dos ecossistemas para a manutenção dos serviços ecossistêmicos e da diversidade biológica. Portanto, sendo um bem de uso comum do povo, é considerado um patrimônio público que deve ser assegurado e protegido, conforme dispõe a Lei $n^{\circ} 6.938$, de 31 de agosto de 1981 - PNMA(BRASIL, 1981).

Nesse sentido, a Política Nacional do Meio Ambiente - PNMA (Lei n 6.938, de 31 de agosto de 1981) conceitua o meio ambiente como "o conjunto de condições, leis, influências e interações de ordem física, química e biológica, que permite, abriga e rege a vida em todas as suas formas" (BRASIL, 1981, art. $3^{\circ}$, inciso I). Ampliando este conceito, o Supremo Tribunal Federal, por meio da Medida Cautelar na Ação Direta de Inconstitucionalidade 3540/2005 reconheceu que o conceito de meio ambiente abarca, além do meio ambiente natural, o meio ambiente artificial, o meio ambiente cultural e o meio ambiente laboral (BRASIL, 2005).

Embora a proteção ao meio ambiente esteja plasmada no texto constitucional e em diversas normas infraconstitucionais, conforme exposto, a expansão das atividades humanas de forma acelerada - tal como a exploração predatória dos habitats naturais, o crescimento desordenado do espaço urbano, o desmatamento, dentre outros - pressiona a manutenção dos serviços prestados pelo meio ambiente natural.

Desse modo, é preciso que haja um diálogo entre os mandamentos constitucionais e infraconstitucionais para que o pleno desenvolvimento das funções sociais da cidade respeite a proteção aos processos naturais do meio ambiente. Com isso em mente, a seguir se analisa a 
interface do Direito Urbanístico com o Direito Ambiental para a garantia da proteção do meio ambiente.

\section{O DIREITO URBANÍSTICO PARA A PROTEÇÃO DO MEIO AMBIENTE}

O Direito Urbanístico serve para o planejamento urbano e tem por finalidade organizar o uso e a ocupação dos espaços habitáveis, inclusive organizar as áreas de interesse especial - como o meio ambiente natural, artificial e cultural (SILVA, 2008). Logo, o Direito Urbanístico, assim como o Direito Ambiental, está diretamente relacionado ao fim de melhorar a qualidade de vida do ser humano (CARMONA, 2015).

Indo além das fronteiras habitáveis, o Direito Urbanístico também deve se ocupar dos espaços não habitáveis, como os ecossistemas naturais, espaços territoriais especialmente protegidos strictu e lato sensu ${ }^{3}$ (MILARÉ, 2015), de modo a regular a pressão exercida pelas atividades humanas nestes (RECH; RECH, 2010), atenuando possíveis impactos ambientais.

Considerando que a qualidade do meio urbano da cidade depende da disponibilidade e qualidade dos serviços ecossistêmicos ${ }^{4}$, a vontade constitucional prevista nos Capítulos do Meio Ambiente e da Política Urbana e as diretrizes do Estatuto da Cidade (BRASIL, 2001) devem ser lidas harmonicamente no tocante à ordem ambiental urbana, visto que, para uma ordem urbanística concretizar o "pleno desenvolvimento das funções sociais da cidade e garantir o bem-estar de seus habitantes" (BRASIL, 1988, art. 182), é necessário o cuidado com a proteção dos ecossistemas e dos seus recursos naturais.

Como visto, a Lei nº 6.938/81 estabelece que o meio ambiente natural é responsável por propiciar a manutenção da vida da sociedade e viabilizar as condições ao desenvolvimento socioeconômico, a proteção da dignidade da vida humana e os interesses da segurança nacional (BRASIL, 1981). Contudo, no tocante à Política Urbana, o texto constitucional não traz nenhuma disposição expressa sobre o meio ambiente, somente prevendo a garantia do bem-estar dos habitantes da cidade (BRASIL, 1988).

Observa-se que o dispositivo constitucional se refere ao bem-estar dos habitantes e à função social que a propriedade deve cumprir conforme o plano diretor. Em que pese a não

\footnotetext{
${ }^{3}$ Os espaços territoriais especialmente protegidos strictu sensu são às diversas categorias de Unidades de Conservação, ao passo que os espaços territoriais especialmente protegidos lato sensu são as Áreas de Preservação Permanente, Reservas Legais e Áreas de Uso Restrito (MILARÉ, 2015).

${ }^{4}$ São serviços ecossistêmicos a ciclagem de nutrientes, o suprimento de água, a reciclagem de materiais, a produção de alimentos, a recuperação de distúrbios naturais, a regulação do fluxo da água, regulação do clima, dentre outros (BENSUSAN, 2008)
} 
referência ao meio ambiente, deve haver uma leitura conforme os mandamentos constitucionais e infraconstitucionais que visam a salvaguarda da biodiversidade.

Estando o bem-estar da população e o cumprimento das funções sociais da cidade relacionados ao meio ambiente, percebe-se a existência de uma via de mão dupla: o meio ambiente só será protegido mediante um planejamento urbano que atente para uma ocupação sustentável (RECH; RECH, 2010), da mesma forma que o meio urbano só será seguro e salubre com a proteção dos ecossistemas naturais, que fornecem os serviços ecossistêmicos e o equilíbrio ambiental para a cidade. Faz-se oportuno, portanto, analisar os dispositivos do Estatuto da Cidade que se relacionam com a proteção do meio ambiente, conforme discorrido no item que se segue.

\section{ANÁLISE DO ESTATUTO DA CIDADE À LUZ DA PROTEÇÃO AMBIENTAL}

O Direito Urbanístico é composto por diversas legislações ${ }^{5}$, sendo o Estatuto da Cidade (Lei $n^{\circ}$ 10.257, de 10 de julho de 2001) a legislação base deste ramo. O Estatuto da Cidade é para o Direito Urbanístico o que o PNMA é para o Direito Ambiental. Ou seja, ambos são responsáveis por regulamentar os dispositivos constitucionais referentes à sua política específica no plano nacional (art. $182, \S 4^{\circ}$ e art. 225 , respectivamente). Outro ponto em comum por ambas as matérias é a preocupação com o meio ambiente, como se verá adiante.

A proteção do meio ambiente natural é necessária pelo Direito Urbanístico, pela capacidade deste - por meio de normas jurídicas - de permitir, restringir e até incentivar o uso adequado do meio ambiente natural (SARNO, 2004). Assim sendo, analisa-se a seguir a possibilidade das diretrizes e regras do Estatuto da Cidade, que se relacionam com o meio ambiente, serem desenvolvidas pelos munícipios para facilitar a implementação de Corredores Ecológicos.

O artigo $1^{\circ}$ institui que o Estatuto da Cidade estabelecerá normas de ordem pública e interesse social que regularão o uso da propriedade privada em benefício do bem coletivo, da segurança e do bem-estar dos cidadãos, bem como do equilíbrio ambiental (BRASIL, 2001).

\footnotetext{
${ }^{5}$ Como a Lei do Tombamento (Decreto-Lei no 25/1937), Lei da Desapropriação (Decreto-Lei $n^{\circ}$ 3.365/1941), Plano Nacional de Desenvolvimento (Lei ${ }^{\circ} 6.151 / 1974$ ), Lei de Parcelamento do Solo (Lei no 7.766/1979), Lei de Acessibilidade Urbana (Lei ${ }^{\circ}$ 10.098/2000), Lei Geral dos Consórcios Públicos (Lei n ${ }^{\circ}$ 11.977/2009), Política Nacional de Resíduos Sólidos (Lei $n^{\circ}$ 12.305/2010), Lei de Saneamento Básico (Lei no 11.445/2007), Política Nacional de Mobilidade Urbana (Lei no 12.587/2012) e Estatuto da Metrópole (Lei n 13.089/2015).
} 
Depreende-se do primeiro dispositivo que as normas urbanísticas devem observar os benefícios não só em prol da população, mas também em prol do meio ambiente.

A menção à atenção ao equilíbrio ambiental de forma expressa é importante pelo fato da proteção ao meio ambiente estar diretamente relacionada aos benefícios anteriormente citados: bem coletivo por ser necessário para a manutenção das vidas, diante da imprescindibilidade dos serviços ecológicos (produção de alimentos, disponibilidade de recursos hídricos, qualidade do ar e do solo, dentre outros); segurança dos cidadãos, ao atuar como uma válvula de segurança contra desastres naturais (EUR-LEX, 2013), tais como assoreamento dos corpos hídricos, enchentes, deslizamento de terras, controle do micro e macroclima, dentre outros; e por, fim, bem-estar dos cidadãos, propiciando oportunidades de recreação e assegurando o equilíbrio do meio ambiente visando a sadia qualidade de vida da população. Observa-se a importância deste primeiro dispositivo como fundamento para a atuação urbanística por meio de perspectivas socioambientais para o alcance de alguns ou todos os benefícios elencados.

$\mathrm{O}$ artigo $2^{\circ}$ traz em seus incisos as diretrizes que a política urbana deverá seguir para alcançar o pleno desenvolvimento das funções sociais da cidade para o bem-estar da população (BRASIL, 2001). As direções do artigo permearão os rumos da política urbana. E, no tocante ao meio ambiente, são importantes para a proteção no sentido amplo - isto é, além do meio ambiente natural, o cultural, o artificial e o laboral.

O inciso I compreende o saneamento ambiental, que é o conjunto de serviços destinados a garantir o adequado abastecimento hídrico, manejo dos resíduos sólidos, proteção do meio ambiente e a conservação dos recursos naturais, de modo a contribuir para a saúde e bem-estar da população, conforme preconiza a Lei no 11.445/07 (BRASIL, 2007). Os incisos II e III do mesmo artigo, ao incluírem como diretrizes a gestão democrática e a cooperação entre entidades públicas e sociedade, em matéria ambiental, traduzem a ideia de uma governança ${ }^{6}$ essencial para a proteção do equilíbrio ecológico e para o desenvolvimento sustentável (BRASIL, 2001).

O inciso IV refere-se ao planejamento para o desenvolvimento das cidades, o qual é fundamental para que haja, na biorregião, uma justa distribuição no espaço socioeconômico e que evite os efeitos negativos sobre o meio ambiente. Por meio de instrumentos como o Plano

\footnotetext{
${ }^{6}$ Uma governança associa o(s) Poder(es) Públicos com o setor privado e organizações da sociedade civil em prol de mudanças e implementações de manejos e projetos comuns de políticas públicas e legislações (LIAN; ROBINSON, 2005).
} 
Diretor e o Zoneamento Ecológico-Econômico, a diretriz concretizada por meio de medidas previstas no planejamento biorregional pode corrigir, evitar e atenuar a distribuição inadequada e os seus efeitos negativos (BRASIL, 2001).

A diretriz do inciso VI trata do que deve ser evitado na ordenação e o controle do uso do solo. Analisando conforme a temática do meio ambiente, a diretrizes previstas nas alíneas "a", "b" e "f" determinam que deve ser evitado a utilização inadequada, os usos incompatíveis ou inconvenientes, bem como a deterioração das áreas urbanizadas (meio ambiente artificial e cultural). Já nas alíneas “g” e "h", prevê-se a ordenação e controle do uso do solo para evitar a poluição, a degradação ambiental e a exposição da população a riscos de desastres ambientais (BRASIL, 2001). O que se observa é a preocupação da legislação com a conservação do meio ambiente natural, artificial e cultural no ordenamento urbano, ao trazer expressamente como diretriz a busca de evitar tais ocorrências no solo urbano.

As cidades possuem uma relação de dependência direta com as atividades rurais, tanto pelas atividades econômicas e sociais, como pelos ecossistemas naturais que são responsáveis por fornecer os serviços ecossistêmicos e regular o macroclima da região. Nesse sentido, o inciso VII do art. $2^{\circ}$ (BRASIL, 2001) apresenta como diretriz da política urbana a "integração e complementaridade entre as atividades urbanas e rurais, tendo em vista o desenvolvimento socioeconômico do Município e do território sob sua área de influência". Essa relação de dependência traz a necessidade do planejamento e do ordenamento territorial por meio de instrumentos urbanísticos - como o Zoneamento Ecológico-Econômico, regulamentado pelo Decreto $\mathrm{n}^{\circ}$ 4.297, de 10 de julho de 2002 (BRASIL, 2002) e o Plano Diretor -, de modo a assegurar o desenvolvimento sustentável da região.

Os incisos VIII, IX e XII, também do art. $2^{\circ}$, refletem a preocupação com a diversidade biológica presente no compromisso internacional do Brasil na Convenção sobre Diversidade Biológica, ratificada pelo Brasil mediante a promulgação do Decreto $\mathrm{n}^{\circ} 2.519$, de 16 de março de 1998. Assinada durante a Conferência das Nações Unidas sobre Meio Ambiente e Desenvolvimento (Rio 92), a Convenção possui como objetivo o tripé: conservação da diversidade biológica, a utilização sustentável de seus componentes e a repartição justa e equitativa dos benefícios derivados da utilização dos recursos genéticos (BRASIL, 1998). Nesse sentido, o inciso XII reflete a preocupação com a conservação do meio ambiente, na sua faceta mais ampla, ao passo que o inciso VIII desenvolve a diretriz 
para a adoção do pilar do uso sustentável, e o inciso IX mira na justa distribuição dos benefícios e ônus do processo de urbanização.

Conversando com a ideia desenvolvida em relação às diretrizes do inciso II e III, o inciso XIII estabelece a participação da população nos processos que envolvam potenciais impactos negativos, visando o pleno desenvolvimento das funções sociais da cidade e a participação da sociedade civil para a efetiva promoção da democracia (BRASIL, 2001). Considerando que as modificações antrópicas podem ter impactos tanto negativos como positivos para a população (MILARÉ, 2015), a participação social é uma etapa indispensável para a concretização ou não dos empreendimentos e traduz a importância do envolvimento da população no exercício do direito-dever de defender e preservar o direito ao meio ambiente ecologicamente equilibrado e o direito à salubridade do espaço habitável.

A diretriz insculpida no inciso XVII traz o estímulo à utilização de "sistemas operacionais, padrões construtivos e aportes tecnológicos" (BRASIL, 2001, art. $2^{\circ}$, inciso XVII) para que, no processo de manejo do parcelamento do solo e das edificações urbanas, ocorra economia de recursos naturais e menos impactos ambientais. Esta é uma diretriz extremamente importante para consecução de um ecodesenvolvimento que garanta o bemestar social por meio do estímulo ao envolvimento de tecnologias, aliando o desenvolvimento do espaço urbano com a proteção e utilização adequada do meio ambiente natural.

Diante da análise das diretrizes anteriores, conclui-se que o Estatuto da Cidade dá grande importância para a pauta ambiental no planejamento urbanístico para efetivar a política urbana (MUKAI, 2019). E, considerando a capacidade dos Corredores Ecológicos Urbanos em conciliarem o desenvolvimento urbano com as questões socioeconômicas enquanto buscam desfragmentar a paisagem por meio da conectividade dos fluxos genéticos entre ecossistemas, acredita-se no potencial destes em representar a concretização das diretrizes quando previstas propostas pelos planejamentos municipais (SILVA et al, 2011).

A seguir se analisará alguns dos instrumentos da política urbana que se relacionam à questão do meio ambiente e que podem contribuir para a implementação dos Corredores Ecológicos. Inicia-se com os planos nacionais, regionais e estaduais e planejamento das regiões metropolitanas, espaço urbano e microrregiões (art. $4^{\circ}$, incisos I e II), os quais são instrumentos primordiais para possibilitar e fortalecer os vínculos com objetivos ambientais visando a segurança jurídica de ações por meio da previsão nos planos e planejamentos. 
O Plano Diretor (art. $4^{\circ}$, inciso III, alínea a) é obrigatório para o planejamento adequado da expansão e transformação do território municipal (MACHADO, 2017), sendo essencial que disponha de um planejamento ambiental. Tratado no Capítulo III pelos incisos 39 a 42-B, o Estatuto da Cidade reitera o mandamento constitucional dos parágrafos do artigo 182 da Constituição Federal (BRASIL, 1988), ao consignar que, para cumprir sua função social, a propriedade deve atender às exigências previstas no plano diretor, sendo este obrigatório para cidades com mais de vinte mil habitantes (BRASIL, 2001).

Infere-se do art. 39, que as necessidades sociais, econômicas e a qualidade de vida dos habitantes são preocupações que devem ser observadas pelo Plano Diretor. No aspecto da qualidade de vida, como desenvolvido anteriormente, não há como afastar a ideia da conservação do meio ambiente natural, devido à dependência dos serviços ecossistêmicos pela população. Ainda, a parte final do dispositivo, ao levantar que as diretrizes do Estatuto devem ser observadas, demonstra que a elaboração do Plano Diretor obrigatoriamente deverá levar em conta os aspectos ambientais anteriormente analisados.

Ainda sobre o Plano Diretor e a relação com o meio ambiente, levanta-se os artigos 42-A e 42-B, incluídos pela Lei da Política Nacional de Proteção e Defesa Civil - PNPDEC (Lei $\mathrm{n}^{\mathbf{0}}$ 12.608, de 10 de abril de 2012), que compreende ações para prevenir, mitigar, preparar os riscos de desastres, bem como responder e recuperar as consequências de desastres, de modo a "promover a continuidade das ações de proteção e defesa civil" (BRASIL, 2012a). O PNPDEC possui entre suas ações para gestão de riscos e de desastres o “cadastro nacional de municípios com áreas suscetíveis à ocorrência de deslizamentos de grande impacto, inundações bruscas ou processos geológicos ou hidrológicos correlatos" (BRASIL, 2012a, art. $6^{\circ}$, inciso VI).

$\mathrm{O}$ art. 42-A determina que os municípios que contenham "áreas suscetíveis à ocorrência de deslizamentos de grande impacto, inundações bruscas ou processos geológicos ou hidrológicos correlatos" tenham, em seu plano diretor medidas de mapeamento e planejamento de ações aptas a prevenir desastres ambientais e, em não sendo as medidas suficientes para evitá-los, que haja planos para realocação das populações que residem em tais áreas de risco. Portanto, a inclusão do dispositivo materializa a integração do PNPDEC com o ordenamento territorial e depreende a preocupação com o meio ambiente natural visto a necessidade deste para a segurança da população. 
O inciso VI do art. 42-A torna obrigatória a identificação e diretrizes para as áreas verdes, visando reduzir a impermeabilização da cidade. E traz a necessidade do Plano Diretor ser compatível com os planos de recursos hídricos, com o objetivo de garantia da disponibilidade de água em quantidade e qualidade para as presentes e futuras gerações, conforme preceitua a Lei no 9.433, de 8 de janeiro de 1997 (BRASIL, 1997).

$\mathrm{O}$ artigo 42-B determina a obrigatoriedade de elaboração de projeto específico para a ampliação do perímetro urbano do município. Para este projeto são estabelecidos requisitos mínimos. Relacionando com a temática do meio ambiente, apontam-se a demarcação do perímetro e a delimitação de áreas com restrições à urbanização e com sujeição ao controle diante de riscos de desastres ambientais e, por fim, o requisito de definir diretrizes e medidas para a proteção do meio ambiente (natural, cultural e artificial).

Considerando os artigos incluídos pelo PNPDEC, acredita-se no potencial dos Corredores Ecológicos Urbanos em atuarem na recuperação e restauração das funções ecológicas, podendo por meio da conectividade da cobertura vegetal fortalecer a proteção e manutenção dos serviços ecossistêmicos e alcançar a prevenção de desastres ambientais e seus riscos aos espaços habitáveis e não habitáveis do território municipal (EUR-LEX, 2013).

O zoneamento ambiental (art. $4^{\circ}$, inciso III, alínea c) é um instrumento do PNMA (BRASIL, 1981) e sua inclusão no Estatuto da Cidade manifesta a importância deste para o êxito de uma organização territorial. Ou seja, terá por fim organizar o território para assegurar a qualidade ambiental, estabelecendo, para tanto, padrões e medidas de proteção ambiental, que devem ser obrigatoriamente observados na implantação de planos, obras e atividades públicas e privadas, conforme dispõe o Decreto no 4.297, de 10 de junho de 2002 (BRASIL, 2002). O zoneamento ambiental visa garantir que a dimensão ambiental seja protegida por meio da planificação dos espaços e seus respectivos usos e ocupações (SANCEVERO, 2007). E, como resultado do planejamento ambiental (MACHADO, 2017), é importante para a conectividade ao prever espaços protegidos, fragmentos de ecossistemas, corredores ecológicos e, assim, viabilizar a criação de projetos para a conexão destas áreas.

O instrumento do estudo prévio de impacto de vizinhança - EIV (art. $4^{\circ}$, inciso VI) é utilizado para a obtenção de licença para empreendimentos e atividades públicas ou privadas no espaço urbano. Não servindo, em nenhuma hipótese, como substitutivo do Estudo de 
Impacto Ambiental ${ }^{7}$. O EIV deve abordar questões relacionadas ao meio ambiente natural, cultural e artificial, cabendo à lei municipal definir os tipos de empreendimentos que é necessária a sua elaboração, tendo por fim expor os impactos positivos e negativos dos empreendimentos construídos, a serem construídos ou a serem ampliados na qualidade de vida da população, conforme dispõem os arts. 36 a 38 do Estatuto da Cidade (BRASIL, 2001). Em relação aos Corredores Ecológicos Urbanos, o EIV é importante para demonstrar os tanto os efeitos positivos, como os negativos (CONSERVATION CORRIDOR, 2020) que pode ocorrer nas conexões entre fragmentos de vegetação.

Já os incentivos e benefícios (art. $4^{\circ}$, inciso IV, alínea c), no que se refere à matéria ambiental, são instrumentos que, por criarem um estímulo econômico, podem alcançar um impacto positivo na concretização das diretrizes e objetivos relacionados à proteção e valorização do meio ambiente e seus recursos naturais. O IPTU verde é um mecanismo sustentável capaz de ser previsto em âmbito municipal para estimular na população uma cultura da preservação do meio ambiente. Isso pela redução do valor do imposto predial e territorial urbano conforme a recuperação e preservação dos recursos naturais existentes na propriedade (JAHNKE et al, 2013).

$\mathrm{O}$ direito de preempção (art. $4^{\circ}$ inciso $\mathrm{V}$, alínea m), previsto nos arts. 25 a 27 do Estatuto da Cidade (BRASIL, 2001), confere ao Poder Público municipal o direito de adquirir um imóvel urbano por meio de uma alienação onerosa entre particulares. Essa faculdade pode ser exercida para fins ambientais, como a "criação de espaços públicos de lazer e áreas verdes", "criação de unidades de conservação ou proteção de outras áreas de interesse ambiental" e "proteção de áreas de interesse histórico, cultural ou paisagístico", segundo previsto nos incisos VI, VII e VIII do art. 26 (BRASIL, 2001). De modo que, o direito de preempção ao conferir ao município a preferência para adquirir um imóvel em áreas de interesse ambiental, pode favorecer a criação de Corredores Ecológicos Urbanos que estão em posicionamentos estratégicos.

A Seção X trata das operações urbanas consorciadas (art. $4^{\circ}$, inciso V, alínea p) e, no $\S 1^{\circ}$ do artigo 32, expressa a missão de uma governança ambiental, ao trazer o conceito de que estas seriam um conjunto de intervenções coordenadas pelo Poder Público com a participação de atores privados, intentando-se transformar as áreas urbanísticas, promover a melhora social

\footnotetext{
${ }^{7} \mathrm{O}$ estudo de impacto ambiental - EIA é uma exigência para que seja possível a expedida a licença ambiental de empreendimentos e atividades consideradas potenciais ou efetivamente causadoras de significativo impacto ambiental (MINISTÉRIO DO MEIO AMBIENTE, 1997).
} 
e a valorização do meio ambiente. Como exemplo, cita-se a construção de corredores para facilitar o fluxo da fauna silvestre, o que pode ser realizado pelo DNIT ou DER conjuntamente com atores privados - podendo ser empresas prestadoras de serviço público, moradores, dentre outros (PREFEITURA DE SÃO PAULO, 2012).

A Seção XI do Capítulo II cuida do instrumento de política urbana para a transferência do direito de construir (art. $4^{\circ}$, inciso V, alínea o), estabelecendo-se no art. 35 que, quando o imóvel for necessário para a preservação do meio ambiente natural, artificial ou cultural, é possível que a Lei municipal - desde que baseada no Plano Diretor - autorize que o proprietário exerça seu direito de construir em outro local ou aliene a propriedade para que o fim de preservação do meio ambiente seja alcançado (BRASIL, 2001). Observa-se a importância deste e seu desenvolvimento no regulamento municipal, de modo a conferir a segurança jurídica ao caso - negocial ou de compensação - em que o poder público possui interesse na propriedade, que pode ser o caso de áreas verdes (BACELLAR et al, 2017).

Como exemplo prático da importância do Estatuto da Cidade para a questão ambiental, em Manaus criou-se o Plano Diretor e Ambiental do Município de Manaus (Lei Complementar $\mathrm{n}^{\mathrm{o}}$ 2, de 16 de Janeiro de 2014), o qual traduz em seus dispositivos a preocupação do município com o meio ambiente. Havendo neste, previsão em um capítulo próprio para os Corredores Ecológicos Urbanos (arts. 67 e 68), o qual reconhece os dois corredores já existentes - o Corredor Ecológico do $\mathrm{Mindu}^{8}$ e o Corredor Ecológico Urbano das Cachoeiras do Tarumã (MANAUS, 2014) - e prevê a criação de outros três (MANAUS, 2014).

Diante da análise dos dispositivos do Estatuto da Cidade, conclui-se a importância de suas diretrizes e seus instrumentos quando trabalhados sob a perspectiva ambiental, para que o ordenamento urbano se desenvolva com segurança e com respeito aos processos ecossistêmicos. Ressalta-se a capacidade do Estatuto de proporcionar o cumprimento de ações ambientais - tal como o Corredor Ecológico Urbano - ao possibilitar a integração da sociedade com a ecologia (SILVA et al, 2011), bem como do Direito Urbanístico com diplomas ambientais. Dessarte, a seguir se analisa o corredor ecológico no âmbito do planejamento urbano como técnica ambientalmente sustentável para a promoção do equilíbrio ambiental.

\footnotetext{
${ }^{8}$ O CEUM foi o primeiro Corredor Ecológico Urbano criado no Brasil e "nasceu dos anseios da população em proteger os remanescentes de matas ciliares ao longo dos igarapés" (SILVA et al, 2018)
} 


\section{O CORREDOR ECOLÓGICO URBANO COMO TÉCNICA AMBIENTALMENTE SUSTENTÁVEL NO PLANEJAMENTO URBANÍSTICO}

A fragmentação do ecossistema causado pelo crescimento urbano tem repercussões tanto na qualidade dos serviços ecossistêmicos, como no aumento da taxa de extinção da diversidade biológica ${ }^{9}$. Isso porque o desaparecimento dos habitats naturais em razão das alterações pelas atividades humanas, bem como a insuficiência das unidades de conservação, levam ao aumento das taxas de extinção das espécies e até ao colapso dos serviços sistêmicos.

A conectividade é necessária para restabelecer o fluxo de biodiversidade entre as áreas protegidas isoladas por meio de ligações ou por meio de rede de corredores, o que fortalece a manutenção da paisagem multiespécie (TSING, 2019). A legislação brasileira prevê e conceitua corredores ecológicos na lei do Sistema Nacional de Unidades de Conservação - SNUC (Lei n 9.985, de 18 de julho de 2000) como:

"porções de ecossistemas naturais ou seminaturais, ligando unidades de conservação, que possibilitam entre elas o fluxo de genes e o movimento da biota, facilitando a dispersão de espécies e a recolonização de áreas degradadas, bem como a manutenção de populações que demandam para sua sobrevivência áreas com extensão maior do que aquela das unidades individuais." (BRASIL, 2000, Art. $2^{\circ}$, inciso XIX)

A previsão legal dos corredores ecológicos é insuficiente, na medida em que protege apenas as ligações entre unidades de conservação, ignorando as conexões entre fragmentos não protegidos. Considerando a dificuldade de alteração em âmbito legislativo para a ampliação da proteção dos corredores, a articulação das legislações urbanísticas e ambientais com as políticas públicas é necessária para possibilitar ligações não apenas entre as unidades de conservação, mas de fragmentos não protegidos pela legislação.

Tais conexões podem e devem estar presentes no espaço urbano, uma vez que um nível adequado de habitabilidade está diretamente relacionado à qualidade do meio ambiente. Como ampliar o tamanho dos espaços verdes também não é uma opção concretizável em muitas realidades, os corredores - como estrutura heterogênea de vegetação - podem ter efeitos positivos ao aumentarem os fatores que conservam a riqueza de espécies nas paisagens urbanas (BENINDE; HOCHKIRCH, 2015).

\footnotetext{
${ }^{9}$ Por diversidade biológica, compreende-se o sentido amplo dado pela Convenção sobre Diversidade Biológica: "significa a variabilidade de organismos vivos de todas as origens, compreendendo, dentre outros, os ecossistemas terrestres, marinhos e outros ecossistemas aquáticos e os complexos ecológicos de que fazem parte; compreendendo ainda a diversidade dentro de espécies, entre espécies e de ecossistemas." (BRASIL, 1998)
} 
Os espaços verdes fragmentados na cidade funcionam como ilhas para um restrito grupo de espécies da biodiversidade urbana (MUNSHI-SOUTH, 2012). Para a teoria da biogeografia de ilhas, isso significaria que, com a diminuição da migração entre estes fragmentos, a taxa de extinção aumentaria (MAC ARTHUR; WILSON, 1967), sendo necessário um planejamento e reflorestamento urbanos para a criação de corredores entre fragmentos de áreas verdes na infraestrutura urbana, de modo a conservar os processos do ecossistema urbano (CAYTON, 2013) e diminuir a tendência do aumento dos impactos da urbanização e fragmentação sobre a biodiversidade urbana (MUNSHI-SOUTH, 2012).

Para Beninde e Hochkirch (2015), aumentar a área de espaços protegidos e criar uma rede de corredores é a estratégia mais importante para manter altos níveis de biodiversidade urbana. Explicam que os fatores abióticos são considerados cruciais para a diversidade biológica, contudo, acreditam que a vegetação - estrutura da vegetação, cobertura de ervas, cobertura de árvores, estrutura de árvores - é o fator de maior influência para a fauna ao prover abrigo e comida.

Há uma grande variedade de habitats verdes no espaço urbano que podem ser objeto de conexão: desde grandes parques urbanos até faixas de áreas verdes que possam servir para conectar população de espécies e também para a dispersão dos indivíduos (CAYTON, 2013). Ainda, há duas formas que mencionamos para corredores ecológicos urbanos: as áreas de preservação permanente e as infraestruturas verdes.

As primeiras podem ser encontradas tanto no espaço rural, como no espaço urbano, segundo a Lei no 12.651, de 25 de maio de 2012, possuindo "a função ambiental de preservar os recursos hídricos, a paisagem, a estabilidade geológica e a biodiversidade, facilitar o fluxo gênico de fauna e flora, proteger o solo e assegurar o bem-estar das populações humanas" (BRASIL, 2012b, art. $3^{\circ}$, inciso II).

No caso das áreas de preservação presentes ao redor de corpos hídricos, além do fornecimento de refúgio para as espécies, têm a importante função para o combate das mudanças climáticas, pois atuam para a qualidade do solo, da água e como regulador do microclima e também para a salubridade da região (KROSBY, THEOBALD, NORHEIM, MCRAE, 2018).

A proteção das áreas de preservação permanente no espaço urbano e de suas conexões com outras áreas verdes é essencial para o bem-estar humano, direta e indiretamente e, também, representa parte do valor econômico total do planeta (CONSTANZA et al, 1997). 
Acerca da infraestrutura verde, como projetos de telhados verdes, tem grande aptidão para conectar espaços verdes urbanos e aumentar a biodiversidade das espécies por meio do aumento da mobilidade destas entre as áreas verdes urbanas conectadas (BRAAKER, et al, 2014).

Sabe-se que os processos de mudança tecnológica, o crescimento populacional e a urbanização interagem entre si e se reforçam mutuamente, o que contribui para a exploração excessiva dos ecossistemas naturais e aumento dos feedbacks negativos dos impactos ambientais (CUMMING et al, 2014). É necessário, desse modo, que medidas para diminuir os feedbacks negativos e ampliar a proteção ao meio ambiente ecologicamente equilibrado conversem com a política urbana, com os diplomas legais urbanísticos e ambientais.

Portanto, a implementação dos corredores ecológicos urbanos como instrumento ambientalmente sustentável é necessária para contornar esse cenário de feedback negativo da fragmentação do meio ambiente natural, contribuindo para a concretização efetiva do direito ao meio ambiente ecologicamente equilibrado e do compromisso constitucional urbanístico de garantir o pleno desenvolvimento das funções sociais da cidade e o bem-estar da população.

\section{CONCLUSÃO}

O meio ambiente é um direito fundamental de terceira dimensão, protegido pela Constituição Federal de 1988, dele fazendo parte o meio ambiente natural, artificial, cultural e laboral, conforme, inclusive, já exposado pelo Supremo Tribunal Federal, quando do julgamento da ADIn 3540/2005. E, como verificado, há uma interface entre o Direito Urbanístico e a matéria ambiental, visto que ambos buscam o equilíbrio ambiental e o bemestar da população.

Essa interface revela o papel essencial que o Direito Urbanístico possui para contornar o cenário de fragmentação dos ecossistemas, de colapso dos serviços ecossistêmicos e de desastres ambientais. Isto, pois, suas legislações têm por fim organizar a ocupação e a utilização tanto de espaços habitáveis, como de espaços não habitáveis, e por se destinarem à melhora na qualidade de vida do ser humano, o dialogo da proteção ambiental com a política urbana é basilar.

$\mathrm{Na}$ análise do Estatuto da Cidade à luz da proteção ambiental, percebe-se que há uma relação estabelecida para a proteção do equilíbrio do meio ambiente, tanto por meio das 
diretrizes que devem permear a política urbana, como por meio dos instrumentos da Lei. E ao observar tal relação com o instrumento dos Corredores Ecológicos Urbanos para a conservação da biodiversidade urbana e, consequentemente, para a melhora do nível de habitabilidade e segurança do espaço urbano, constata-se a capacidade do Estatuto em viabilizar e fortalecer a criação destes por meio de uma previsão na política urbana e planejamentos urbanísticos.

Por fim, considerando o grande potencial de ações ambientais sustentáveis para o cumprimento do pleno desenvolvimento urbano, conclui-se que o Direito Urbanístico, por meio de sua legislação base de política urbana, é primordial para estimular e conferir segurança jurídica da criação à proteção dos Corredores Ecológicos Urbanos.

\section{REFERÊNCIAS}

BACELLAR, Isabela; FURTADO, Fernanda; NEWLANDS, Akhiris. A experiência munipal recente com a Transferência do Direito de Construir no Brasil: imprecisões, lacunas e oportunidades de aperfeiçoamento. Congresso Iberoamericano de suelo urbano: El suelo em la nueva agenda urbana. Curitiba, Brasil. 23 al 25 de agosto de 2017. Disponível em:

https://d1wqtxts1xzle7.cloudfront.net/55564363/2017_III_CISU_TDC_Bacellar_Furtado_e_N ewlands.pdf?1516203842=\&response-content-

disposition=inline\%3B+filename\%3D2017_III_CISU_TDC_Bacellar_Furtado_e_New.pdf\&Ex pires $=1600733409 \&$ Signature $=X F 9 f e R 8 a \bar{W} n \bar{T} U A m \bar{h} V H j T h U y j E R \sim \overline{9} s 9 Z x i O h M \bar{W}$ uoXcE svB vuckNWJWdtZIZxBE5CPLUeLm5s5dtoyID9aTjx7V8wXSz1 xyoQLIrFGRzSmM1aQBoVeoq2 XLt5LgGgkaVvoLWIpJQ6E SFJXgHLoP7XWPBSbqwFAxN0HVyQv6J5bOk-

INOTulRO bnrv2CFBICdEjTmhMsTf3E1 oPOFmUO6ITDitv9CqellvgB3jTcl DPZx5WVHqF3 GNjNnyQjr8ObDmJfnklwVxfmUMql3HkL2YS705J05ThyhzSkJqODt9bwTdzX SPmoCIMOD 3QiNtwRVfOSYxAR34S5xweFniXw_\&Key-Pair-ld=APKAJLOHF5GGSLRBV4ZA. Acesso em 21 set 2020.

BENINDE, Joscha; VEITH, Michael; HOCHKIRCH, Axel. Biodiversity in cities space: a meta-analysis of factors determining intra-urban biodiversity variation. Ecology Letters, Volume 18, Issue 6. 10 de abril de 2015. Disponível em: https://doi.org/10.1111/ele.12427. Acesso em 24 ago 2020.

BENSUSAN, Nurit. O que a natureza faz por nós: serviços ambientais. In:

BENSUSAN, Nurit (org). Seria melhor ladrilhar? Biodiversidade: como, para que e por quê. 2008, $2^{\text {a }}$ Edição. São Paulo/SP: Peirópolis; Brasília/DF: Editora Universidade de Brasília.

BRAAKER, S., GHAZOULS, Jaboury, OBRIST, M. K., MORETTI, Marco. Habitat connectivity shapes urban arthropod communities: the key role of green roofs. ECOLOGY: Ecologocial Society of America, 1 Abril de 2014. Disponível em: https://doi.org/10.1890/13-0705.1. Acesso em 21 ago 2020. 
BRASIL. Constituição da República Federativa do Brasil de 1988. Brasília, DF: Presidência da República, 2020. Disponível em: http://www.planalto.gov.br/ccivil_03/constituicao/constituicao.htm. Acesso em: 06 ago. 2020.

BRASIL. Decreto $\mathrm{n}^{\circ}$ 4.297, de 10 de julho de 2002. Regulamenta o art. 9o, inciso II, da Lei no 6.938, de 31 de agosto de 1981, estabelecendo critérios para o Zoneamento EcológicoEconômico do Brasil - ZEE, e dá outras providências. Disponível em: http://www.planalto.gov.br/ccivil_03/decreto/2002/D4297.htm. Acesso em 11 ago 2020.

BRASIL. Lei $\mathbf{n}^{\mathbf{0}}$ 6.938, de 31 de agosto de 1981. Dispõe sobre a Política Nacional do Meio Ambiente, seus fins e mecanismos de formulação e aplicação, e dá outras providências. http://www.planalto.gov.br/ccivil_03/LEIS/L6938.htm. Acesso em: 06 ago. 2020.

BRASIL. Lei $\mathbf{n}^{\mathbf{0}}$ 9.433, de 8 de janeiro de 1997. Institui a Política Nacional de Recursos Hídricos, cria o Sistema Nacional de Gerenciamento de Recursos Hídricos, regulamenta o inciso XIX do art. 21 da Constituição Federal, e altera o art. $1^{\circ}$ da Lei ${ }^{\circ}$ 8.001, de 13 de março de 1990, que modificou a Lei $n^{\circ} 7.990$, de 28 de dezembro de 1989. Disponível em: http://www.planalto.gov.br/ccivil_03/LEIS/L9433.htm. Acesso em 28 ago 2020.

BRASIL. Decreto $\mathbf{n}^{\circ}$ 2.519, de 16 de março de 1998. Promulga a Convenção sobre Diversidade Biológica, assinada no Rio de Janeiro em 05 de junho de 1992. Disponível em: http://www.planalto.gov.br/ccivil_03/decreto/D2519.htm. Acesso em: 16/09/2020.

BRASIL. Lei no 9.985, de 18 de julho de 2000. Regulamenta o art. 225, § 1o, incisos I, II, III e VII da Constituição Federal, institui o Sistema Nacional de Unidades de Conservação da Natureza e dá outras providências. Disponível em: http://www.planalto.gov.br/ccivil_03/leis/19985.htm. Acesso em 06 ago 2020.

BRASIL. Lei $\mathbf{n}^{\mathbf{0}} \mathbf{1 0 . 2 5 7}$, de 10 de julho de 2001. Regulamenta os arts. 182 e 183 da Constituição Federal, estabelece diretrizes gerais da política urbana e dá outras providências. Disponível em: http://www.planalto.gov.br/ccivil_03/leis/leis_2001/110257.htm. Acesso em 06 ago 2020.

BRASIL. Lei $\mathbf{n}^{\mathbf{0}}$ 12.608, de 10 de abril de 2012. Institui a Política Nacional de Proteção e Defesa Civil - PNPDEC; dispõe sobre o Sistema Nacional de Proteção e Defesa Civil SINPDEC e o Conselho Nacional de Proteção e Defesa Civil - CONPDEC; autoriza a criação de sistema de informações e monitoramento de desastres; altera as Leis $\mathrm{n}^{\circ} \mathrm{s} 12.340$, de $1^{\circ}$ de dezembro de 2010, 10.257, de 10 de julho de 2001, 6.766, de 19 de dezembro de 1979, 8.239, de 4 de outubro de 1991, e 9.394, de 20 de dezembro de 1996; e dá outras providências. Brasília, 2012a. Disponível em: http://www.planalto.gov.br/ccivil_03/_Ato20112014/2012/Lei/L12608.htm. Acesso em 16 ago 2020.

BRASIL. Lei $n^{\circ}$ 11. 445, de 5 de janeiro 2007. Estabelece as diretrizes nacionais para o saneamento básico; cria o Comitê Interministerial de Saneamento Básico; altera as Leis nos 6.766, de 19 de dezembro de 1979, 8.666, de 21 de junho de 1993, e 8.987, de 13 de fevereiro de 1995; e revoga a Lei $\mathrm{n}^{\mathrm{o}}$ 6.528, de 11 de maio de 1978 . Disponível em: http://www.planalto.gov.br/ccivil_03/_ato2007-

2010/2007/lei/111445.htm\#: :text=LEI\%20N\%C2\%BA\%2011.445\%2C\%20DE\%205\%20DE \%20JANEIRO\%20DE\%202007.\&text=. Acesso em 16 ago 2020.

BRASIL. Lei $\mathbf{n}^{\mathbf{0}} \mathbf{1 2 . 6 5 1}$, de 25 de maio de 2012. Dispõe sobre a proteção da vegetação nativa; altera as Leis $\mathrm{n}^{\circ} \mathrm{s}$ 6.938, de 31 de agosto de 1981, 9.393, de 19 de dezembro de 1996, e 11.428, de 22 de dezembro de 2006; revoga as Leis $\mathrm{n}^{\circ} \mathrm{s} 4.771$, de 15 de setembro de 1965, e 
7.754, de 14 de abril de 1989, e a Medida Provisória n 2.166-67, de 24 de agosto de 2001; e dá outras providências. Brasília, 2012b. Disponível em: http://www.planalto.gov.br/ccivil_03/_Ato2011-2014/2012/Lei/L12651compilado.htm. Acesso em 29 ago 2020.

BRASIL. Supremo Tribunal Federal. Tribunal Pleno. Mandado de Segurança $\mathbf{n}^{\mathbf{0} 22.164-0}$ São Paulo. Ementa: Reforma Agrária - Imóvel Rural Situado no Pantanal Mato-Grossense Desapropriação-Sanção (CF, art. 184) - possibilidade - falta de notificação pessoal e prévia do proprietário rural quanto à realização da vistoria (Lei $n^{\circ} 8.629 / 93$, art. $2^{\circ}, \S^{\circ}$ ) - Ofensa ao Postulado do due processo f law (CF, art. $5^{\circ}$, LIV) - Nulidade radical da declaração expropriatória - Mandado de Segurança deferido. Tribunal Pleno. Relator: Ministro Celso de Mello. Data do Julgamento: 30 out 1995. Disponível em: http://redir.stf.jus.br/paginadorpub/paginador.jsp?docTP=AC\&doclD=85691. Acesso em 17 set 2020.

BRASIL. Supremo Tribunal Federal. Tribunal Pleno. Medida Cautelar em Ação Direta de Inconstitucionalidade 3.540-1 Distrito Federal. Ementa: meio ambiente - direito à preservação de sua integridade (CF, art. 225) - prerrogativa qualificada por seu caráter de metaindividualidade - Direito de Terceira Geração (ou de novíssima dimensão) que consagra o postulado da solidariedade - necessidade de impedir que à transgressão a esse direito faça irromper, no seio da coletividade, conflitos intergeneracionais - espaços territoriais especialmente protegidos $\left(\mathrm{CF}\right.$, art. $225, \S 1^{\circ}$, iii) - alteração e supressão do regime jurídico a eles pertinente - medidas sujeitas ao princípio constitucional da reserva de lei - supressão de vegetação em área de preservação permanente - possibilidade de a administração pública, cumpridas às exigências legais, autorizar, licenciar ou permitir obras e/ou atividades nos espaços territoriais protegidos, desde que respeitada, quanto a estes, a integridade dos atributos justificadores do regime de proteção especial - relação entre economia $\left(\mathrm{CF}\right.$, art. $3^{\circ}$, ii, c/c o art. 170, Vi) e ecologia (CF, art. 225) - colisão de direitos fundamentais - critérios de superação desse estado de tensão entre valores constitucionais relevantes - os direitos básicos da pessoa humana e às sucessivas gerações (fases ou dimensões) de direitos (RTJ 164/158, 160-161) - a questão da precedência do direito à preservação do meio ambiente: uma limitação constitucional explícita à atividade econômica (Cf, art. 170, vi) - decisão não referendada - consequente indeferimento do pedido de medida cautelar. Tribunal Pleno. Relator: Min. Celso de Mello. Data do Julgamento: 01 set. 2005. Data da publicação: 03 fev. $2006 . \quad$ Disponível em: http://redir.stf.jus.br/paginadorpub/paginador.jsp?docTP=AC\&docID=387260. Acesso em 06 ago. 2020.

CARMONA, Paulo Afonso Cavichioli. Curso de Direito Urbanístico. Salvador: Juspodivm/FESMPDFT, 2015.

CAYTON, Heather. Landscape genomics of dispersal corridors in NYC. 8 de março de 2013. Disponível em: http://conservationcorridor.org/2013/03/landscape-genomics-ofdispersal-corridors-in-new-york-city/. Acesso em 21 ago 2020.

CONSERVATION CORRIDOR. Corridor Concerns. 2020. Disponível em: https://conservationcorridor.org/corridor-concerns/. Acesso em 21 set 2020.

COSTANZA, R.; D'ARGE, R.; DE GROOT, R. et al. The value of the world's ecosystem services and natural capital. Nature 387, 253-260 (1997). Disponível em: https://doi.org/10.1038/387253a0. Acesso em 24 ago 2020. 
CUMMING, G., BUERKERT, A., HOFFMANN, E. et al. Implications of agricultural transitions and urbanization for ecosystem services. Nature 515, 50-57 (2014). Disponível em: https://doi.org/10.1038/nature13945. Acesso em 24 ago 2020.

DIAMOND, Jared. O colapso: como as sociedades escolhem o fracasso ou o sucesso. $5^{\text {a }}$ Ed. Rio de Janeiro/São Paulo: Editora Record, 2007.

EUR-LEX. Communication from the commission to the European Parliament, the council, the european economic and social committee and the committee of the regions. Green Infrastructure (GI) - Enhacing Europe's Natural Capital. 2013. Disponível em: https://eur-lex.europa.eu/legal-

content/EN/TXT/HTML/?uri=CELEX:52013DC0249\&from=EN. Acesso em 26 jul. 2020

HADDAD, Nick. Riparian restoration as a way to create climate corridors. Conservation Corridors, 30 de novembro de 2018. Disponível em: http://conservationcorridor.org/2018/11/riparian-restoration-as-a-way-to-create-climatecorridors/. Acesso em 21 ago 2020.

JAHNKE, Letícia Thomasi; WILANI, Sheila Marione Uhlmann; ARAÚJO, Tiago Luiz Rigon de Araújo. O IPTU VERDE: Práticas sustentáveis trazem benefícios financeiros à população. Revista Eletrônica do Curso de Direito. Universidade Federal de Santa Maria. ISSN 1981-3694. V. 8, 2013. Disponível em: https://periodicos.ufsm.br/revistadireito/article/view/8341. Acesso em 17 set 2020.

KROSBY, Meade, THEOBALD, David M., NORHEIM, Robert, MCRAE, Brad H. Identifying riparian climate corridors to inform climate adaptation planning. 2018. PLoS ONE 13(11): e0205156. Disponível em: https://doi.org/10.1371/journal.pone.0205156. Acesso em 21 ago 2020.

LIAN, KOH KHENG; ROBINSON, Nicholas A. Governança ambiental regional: exame do modelo da Associação das Nações do Sudeste Asiático. In: ESTY, Daniel C.; IVANOVA, Maria H. (orgs). Governança Ambiental Global. São Paulo: Editora Senac São Paulo, 2005.

MAC ARTHUR, Robert H; WILSON, Edward O. The Theory of Island Biogeography. New Jersey: Princeton University Press, 1967.

MACHADO, Paulo Affonso Leme. Direito Ambiental brasileiro. 25ed., ver., ampl., e atual., São Paulo: Malheiros, 2017.

MANAUS. Lei Complementar n⿳2, de 16 de janeiro de 2014. Dispõe sobre o Plano Diretor Urbano e Ambiental do Município de Manaus e dá outras providências. Disponível em: https://leismunicipais.com.br/plano-diretor-manaus-am. Acesso em 20 set 2020.

MILARÉ, Édis. Direito do Ambiente. 10ed. rev, atual. e ampl. São Paulo: Editora Revista dos Tribunais, 2015.

MINISTÉRIO DO MEIO AMBIENTE. Projeto Corredores Ecológicos. 2020. Disponível em <https://www.mma.gov.br/areas-protegidas/programas-e-projetos/projeto-corredoresecologicos>. Acesso em 17 ago 2020.

MINISTÉRIO DO MEIO AMBIENTE. Resolução Conama no 237, de 19 de dezembro de 1997.

Disponível

em

https://www.icmbio.gov.br/cecav/images/download/CONAMA\%20237_191297.pdf. Acesso em 19 ago 2020.

Revista de Direito Urbanístico, Cidade e Alteridade | e-ISSN: 2525-989X | Encontro Virtual | v. 6 |

n. 2 | p. 93 - 113 | Jul/Dez. 2020. 
MUKAI, Toshio. O Estatuto da Cidade: anotações à Lei n. 10.257/2001. $4^{\mathrm{a}}$ Ed. São Paulo: Saraiva Educação, 2019.

MUNSHI-SOUTH, Jason. Urban landscape genetics: canopy cover predicts gene flow between white-footed mouse (Peromyscus leucopus ) populations in New York City. Molecular Ecology, Volume, 21, Isuue 6, 9 de fevereiro de 2012. Disponível em: https://doi.org/10.1111/j.1365-294X.2012.05476.x. Acesso em 21 ago 2020.

PREFEITURA DE SÃO PAULO. Operações Urbanas Consorciadas. 17 jan 2012. Disponível

https://www.prefeitura.sp.gov.br/cidade/secretarias/obras/sp_obras/operacoes_urbanas/\#: :t ext=Opera\%C3\%A7\%C3\%B5es\%20urbanas $\% 20$ consorciadas $\% 20$ s\%C3\%A30\%20interven \%C3\%A7\%C3\%B5es,melhorias\%20sociais\%20e\%20valoriza\%C3\%A7\%C3\%A30\%20ambie ntal. Acesso em 21 set 2020.

RECH, Adir Ubaldo; RECH, Adivandro. Direito Urbanístico: fundamentos para construção de um plano diretor sustentável na área urbana e rural. Rio Grande Do Sul/RS: Educs, 2010.

SARLET, Ingo Wolfgang. A Eficácia dos Direitos Fundamentais. Porto Alegre/ RS: Livraria do Advogado Editora Ltda, 2015.

SARLET, Ingo Wolfgang; FENSTERSEIFER, Tiago. Direito Constitucional Ambiental: Constituição, Direitos Fundamentais e Proteção do Ambiente. $5^{\text {a }}$ Ed. rev., atual., e ampl. São Paulo: Editora Revista dos Tribunais, 2017.

SARNO, Daniela Campos Libório. Elementos de direito urbanístico. Barueri, SP: Manole, 2004.

SILVA, Fabrícia Souza da; OLIVEIRA, Lindalva Samela Jacauna de; TERÁN, Augusto Fachin; MACHADO, Ailton Cavalcante. Corredor Ecológico Urbano do Mindu: um relato de experiência sobre práticas de educação ambiental. Educação Ambiental. ISSN 1678-0701. Número 66, Ano XVII. Dezembro/2018-Fevereiro 2019. No. 66 - 06/12/2018. Disponível em: http://www.revistaea.org/artigo.php?idartigo=3514. Acesso em 20 set 2020.

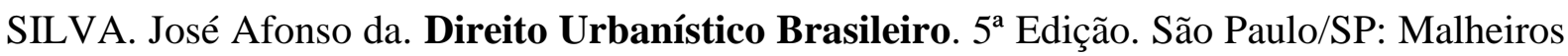
Editores LTDA, 2008.

SILVA, Mariana Mendes; SANTOS, Douglas Gomes dos; REIS, Laís Naiara Gonçalves dos; SILVA, Nathalie Ribeiro; FARIA, Polyana de Oliveira. Uma proposta de corredor ecológico para o município de Uberlândia/MG. Observatorium: Revista Eletrônica de Geografia, v.3, n. 7, p. 115-133, out. 2011. Disponível em http://www.observatorium.ig.ufu.br/pdfs/3edicao/n7/8.pdf. Acesso em 20 set 2020.

TSING, Anna Lowenhaupt. Viver nas ruínas: paisagens multiespécies no antropoceno. Brasília: IEB Mil Folhas, 2019. 